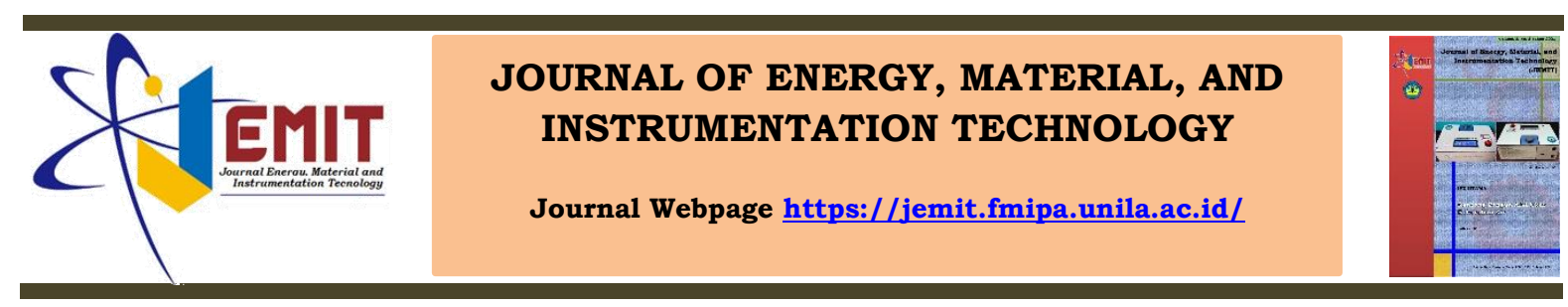

\title{
Kajian Simulasi Dinamika Molekul Adsorpsi Hidrogen pada Carbone Nanotube dengan Variasi Chirality dan Temperatur Menggunakan Kode LAMMPS
}

\author{
Erika Marinda Mufidaa, Sri Wahyu Suciyatib, Gurum Ahmad Pauzic, dan Amir \\ Supriyanto
}

Jurusan Fisika, Universitas Lampung, Bandar Lampung, Indonesia, 35141

\begin{tabular}{|c|c|}
\hline Article Information & Abstract \\
\hline $\begin{array}{l}\text { Article history: } \\
\text { Received April 20th, } 2021 \\
\text { Received in revised form } \\
\text { May 10th, } 2021 \\
\text { Accepted May 17th, } 2021\end{array}$ & $\begin{array}{l}\text { Hydrogen adsorption has been simulated on carbon nanotubes for optimum } \\
\text { hydrogen absorption. Parameters that affect the amount of hydrogen absorbed } \\
\text { have been studied, such as the effect of chirality and temperature on hydrogen } \\
\text { absorption in CNTs. The simulation method of hydrogen adsorption on carbone } \\
\text { nanotubes uses molecular dynamics simulation code LAMMPS, applies Lennard- } \\
\text { Jones interatomic potential and hydrogen atom movement using Van Der Waals } \\
\text { force with Microcanonical Ensemble. Data analysis is the output of LAMPS in the } \\
\text { form of data in XYZ format. The data contains information in the form of } \\
\text { integration steps, number of atoms, temperature, pressure, potential energy, } \\
\text { kinetic energy, volume, van der waals energy, total simulation time and } \\
\text { hydrogen absorption. The simulation results show that the optimum absorption } \\
\text { occurs at run } 1000 O \text { and a temperature of } 100 \mathrm{~K} \text {, for armchair chirality of } 10 \\
\text { atoms, chirality of } 12 \text { atoms and zigzag chrality of } 5 \text { atoms. Formation of } \\
\text { hydrogen coordinates with Avogadro software, formation of CNT coordinates } \\
\text { with VMD software and visualization of hydrogen adsorption on CNTs using } \\
\text { VMD software. }\end{array}$ \\
\hline Informasi Artikel & Abstrak \\
\hline $\begin{array}{l}\text { Proses artikel: } \\
\text { Diterima } 20 \text { April } 2021 \\
\text { Diterima dan direvisi dari } \\
10 \text { Mei } 2021 \\
\text { Accepted } 17 \text { mei } 2021\end{array}$ & $\begin{array}{l}\text { Telah disimulasikan adsorpsi hidrogen pada carbone nanotube untuk } \\
\text { penyerapan optimum hidrogen. Parameter yang mempengaruhi banyaknya } \\
\text { hidrogen terserap telah dikaji, seperti pengaruh chirality dan temperatur } \\
\text { terhadap penyerapan hidrogen pada CNT. Metode simulasi adsorpsi hidrogen } \\
\text { pada carbone nanotube menggunakan simulasi dinamika molekul kode } \\
\text { LAMMPS, menerapkan potensial interatomik Lennard-Jones dan pergerakan } \\
\text { atom hidrogen menggunakan gaya Van Der Waals dengan Ensemble } \\
\text { Mikrokanonikal. Data analisis merupakan keluaran dari LAMMPS berupa data } \\
\text { dengan format XYZ. Data tersebut berisi informasi berupa step integrasi, } \\
\text { jumlah atom, temperatur, tekanan, energi potensial, energi kinetik, volume, } \\
\text { energi van der waals, total waktu simulasi dan penyerapan hidrogen. Hasil } \\
\text { simulasi menunjukkan bahwa penyerapan optimum terjadi pada run 10000 } \\
\text { dan temperatur } 100 \mathrm{~K} \text {, untuk chirality armchair sebesar } 10 \text { atom, chirality } \\
\text { chiral sebesar } 12 \text { atom dan chrality zigzag sebesar } 5 \text { atom. Pembentukkan } \\
\text { koordinat hidrogen dengan software Avogadro, pembentukan koordinat CNT } \\
\text { dengan sofware VMD dan visualisasi adsorpsi hidrogen pada CNT } \\
\text { menggunakan software VMD. }\end{array}$ \\
\hline
\end{tabular}

\section{Pendahuluan}

Salah satu energi alternatif yang diminati oleh para peneliti adalah hidrogen (Dzulfahmi, 2012). Hidrogen adalah unsur yang terkandung di alam, sumber energi bersih namun tidak dapat ditambang seperti sumber energi konvensional BBM (Bahan Bakar Minyak). Sedikitnya unsur polutan yang dihasilkan oleh hidrogen merupakan suatu kelebihan untuk menjadi sumber energi masa depan yang terbarukan (Chandrasa, 2009). Gas hidrogen $\left(\mathrm{H}_{2}\right)$ merupakan gas yang memiliki kelimpahan paling besar yaitu $75 \%$ penyusun alam semesta dan hampir $90 \%$ membentuk unsur di alam. Di bumi hidrogen bersenyawa dengan unsur oksigen membentuk senyawa $\mathrm{H}_{2} \mathrm{O}$ yang sering disebut dengan air (Afief dan Isana, 2017). Gas hidrogen cocok untuk konversi energi tanpa menghasilkan

* Corresponding author.

E-mail addres: (a*) erikammufida1998@gmail.com, (b) ayoe1971@fmipa.unila.ac.id, (c) gurum@fmipa.unila.ac.id 
emisi karbon, karena gas hidrogen $\left(\mathrm{H}_{2}\right)$ mempunyai gravimetrik densitas energi yang tertinggi diantara beberapa bahan bakar lainnya (Hakim dan Marsalin, 2016).

Membuat bahan bakar dari hidrogen lebih mudah, akan tetapi kendala yang harus di hadapi antara lain hidrogen harus disimpan terlebih dahulu sebelum diproduksi menjadi bahan bakar (Saputri, 2018). Sedangkan kekurangannya adalah sering mengalami kebocoran pada tangki (Kurniady dkk, 2014). Persoalan penyimpanan hidrogen dapat diatasi dengan menyimpan hidrogen pada karbon yang merupakan material berpori, biaya operasi relatif murah, molekul yang cukup ringan membuat atom karbon sangat cocok sebagai media penyimpanan hidrogen dengan total tangki penyimpanan yang ringan (Prasodjo, 2010).

Adsorpsi secara umum adalah substansi terlarut dalam larutan yang mengalami proses penggumpalan oleh permukaan suatu benda atau zat penyerap, sedangkan absorpsi terjadi ketika zat padat dimasuki oleh bahan yang mengumpul. Keduanya sering muncul bersamaan dengan suatu proses maka ada yang menyebutnya sorpsi (Giyatmi dkk, 2008). Adsorpsi dapat terjadi karena adanya gaya tarik-menarik. Akibat koordinasi ikatan hidrogen dan gaya Van der Waals. Pada saat permukaan adsorben dan adsorbat terikat oleh gaya Van der Waals, maka terjadilah adsorpsi fisis (Widayatno dkk, 2017). Karakteristik penting suatu sistem Penyimpanan Hidrogen antara lain reversibilitas penyerapan dan pelepasan, sehingga pemilihan bahan yang mampu berinteraksi dengan hidrogen, serta bahan inert menjadi penting (Zuttel, 2003). Pembuatan bahan bakar hidrogen sangat mudah, namun kendalanya pada penyimpanan hidrogen yang harus dilakukan sebelum diproduksi menjadi bahan bakar (Saputri, 2018). CNT merupakan hasil teknologi nano digunakan dalam bidang pengetahuan seperti bidang kimia, bidang elektronik dan lain-lain (Sutanti dan Yani, 2013). CNT berbentuk silinder, dengan salah satu ujung CNT terbuka dan ujung lain ditutup dengan fullerene penuh. Nama CNT berasal dari ukurannya, karena diameter CNT berada di urutan beberapa nanometer (kira-kira 50.000 kali lebih kecil dari lebar rambut manusia) sampai beberapa mikrometer.

Carbone Nanotube (CNT) merupakan media penyimpanan yang baik, karena memiliki luas permukaan dan volume pori yang besar, melalui pemodelan dan simulasi dinamika molekuler dapat dianalisis energi interaksi adsorpsi hidrogen dengan CNT (Lago, 2016). Dinamika molekul merupakan metode simulasi dengan komputer yang memungkinkan representasi molekul atom dalam periode waktu tertentu (Astuti dan Mutiara, 2009). Penelitian Dzulfahmi (2012) menggunakan simulasi dinamika molekuler adsorpsi hidrogen pada CNT dengan variasi penyerapan dua puluh molekul hidrogen pada tempratur $10 \mathrm{~K}$. Penelitian lain mengenai adsorpsi hidrogen pada carbon nanotube juga dilakukan oleh Santoso, 2012 mengenai "Simulasi Dinamika Molekuler Adsorpsi Hidrogen Pada Carbone Nanotubes (CNT) menggunakan variasi chirality dengan chairlity yang digunakan adalah hasil variasi dari penelitian maruyama $(2000)$ yaitu sebesar $(8,8),(10,10)$ dan $(12,12)$. Jabbar, pada tahun 2012 juga melakukan penelitian adsorpsi hidrogen pada CNT dengan variasi temperatur $253 \mathrm{~K}, 273 \mathrm{~K}$ dan $293 \mathrm{~K}$, hasil penyerapan hidrogen yang diperoleh pada temperatur $253 \mathrm{~K}$ lebih baik dari temperatur $273 \mathrm{~K}$ dan $293 \mathrm{~K}$. Penelitian lain tentang adsorpsi hidrogen pada graphene dilakukan oleh Kurniady dkk, 2014 yang menganalisis pengaruh suhu, tekanan dan ukuran pori graphene terhadap dinamika molekuler. Hasil penelitian Kurniady dkk, (2014) dengan dua iterasi berbeda yakni 100000 dan 150000, dimana lebar pori-pori yang digunakan adalah variasi yang pernah digunakan pada penelitian Julio A. Alonso sebesar 6, 8 dan $10 \AA$. .

Avogadro merupakan editor dan visualisasi molekul tingkat lanjut, dirancang untuk digunakan dalam kimia komputasi (Rayan dan Rayan, 2017). Visual Molecular Dynamics (VMD) merupakan program grafik molekuler yang dirancang untuk tampilan dan analisis perakitan molekul. VMD ditulis dalam $\mathrm{C}++$, menggunakan desain berorientasi objek, program, termasuk kode sumber dan dokumentasi ekstensif (Humphrey dkk, 1996). LAMMPS (Large-scale Atomic/Molecular Massively Parallel Simulator) adalah sebuah perangkat lunak open source yang dikembangkan oleh Sandia National Laboratories (Hidayat, 2019). LAMMPS mengintegrasikan persamaan gerak Newton untuk kumpulan atom, molekul, atau partikel makroskopik yang berinteraksi melalui gaya jarak pendek atau jarak jauh dengan variasi kondisi awal atau batas.

Tujuan simulasi dinamika molekul pada artikel ini adalah memprediksi adsorpsi hidrogen pada CNT melalui variasi ukuran CNT untuk penyimpanan hidrogen menggunakan LAMMPS. Kajian simulasi dinamika molekul ini, antara lain menganalisis file output LAMMPS berupa data energi interaksi, tekanan dan waktu simulasi, serta menganalisis hasil simulasi adsorpsi hidrogen pada CNT berupa visualisasi tiga dimensi pada software VMD (Visual Molecular Dynamics). Hasil yang diharapkan berupa kode perangkat lunak LAMMPS yang berkoordinasi dengan software Avogadro dan VMD.

\section{Metode Penelitian}

Pelaksanaan penelitian dilakukan di Laboratorium Elektronika Dasar Jurusan Fisika Fakultas Matematika dan Ilmu Pengetahuan Alam Universitas Lampung. Alat yang digunakan pada penelitian ini adalah komputer yang diinstal sistem operasi windows 2010 pro dengan RAM 4 GB dan processor intel core i5-8250U. Untuk bahan yang digunakan adalah software program LAMMPS dan Command Prompt serta software Avogadro dan VMD. Prosedur penelitian yang dilakukan terdiri dari langkah simulasi pada software Avogadro, VMD dan program LAMMPS. Secara umum prosedur penelitian ditunjukkan pada Gambar 1. 


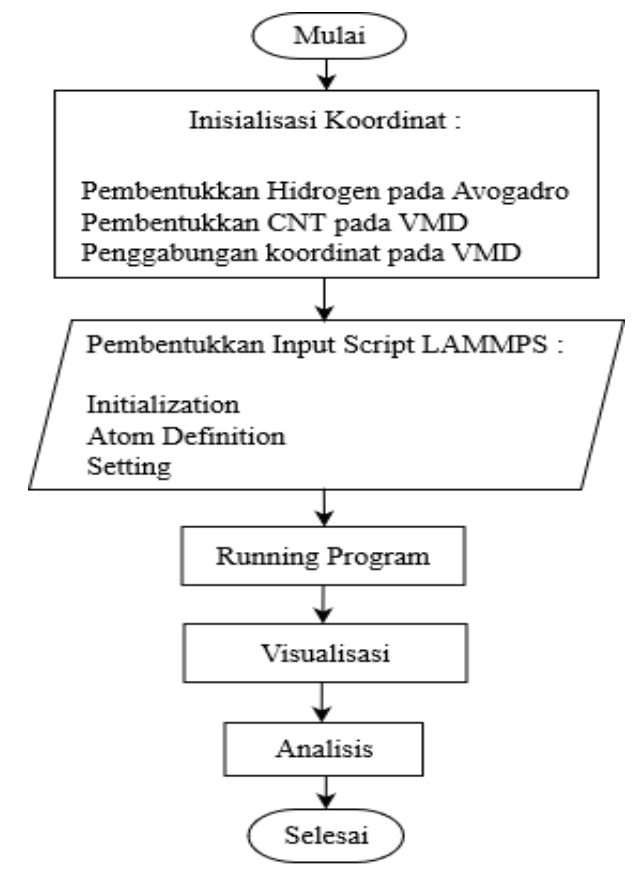

Gambar 1. Diagram Alir Penelitian

\subsection{Prosedur Simulasi}

Program Avogadro. Membuat inisialisasi atom dan molekul hidrogen dengan meletakkan posisi atom hidrogen pada posisi awal secara bebas.

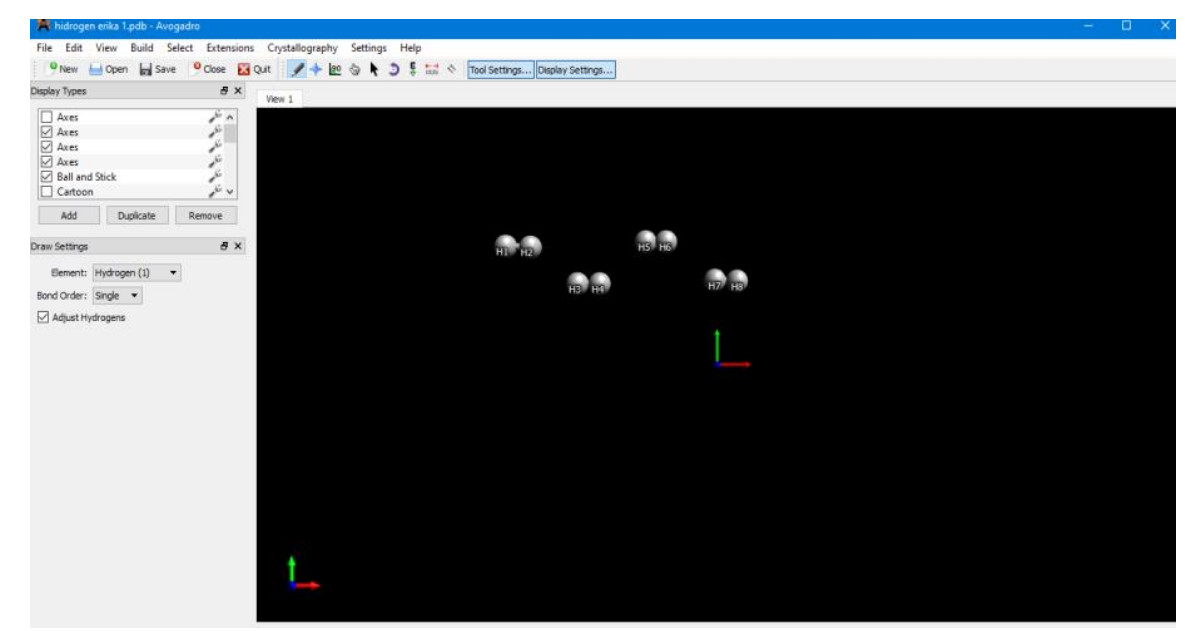

Gambar 2. Pembentukkan Hidrogen pada Avogadro

Pada program Avogadro setelah diperoleh koordinat maka di dapat output file yang berisi koordinat sumbu $\mathrm{x}, \mathrm{y}$ dan $z$. Koordinat dapat diubah-ubah sesuai dengan kebutuhan simulasi.

Program VMD. Membuat inisialisasi koordinat atom Carbon Nanotube serta memvisualisasikan hasil simulasi seperti pada Gambar 3. 
Mufida EM, Suciyati SW, Pauzi GA, dan Supriyanto A, 2021, Kajian Simulasi Dinamika Molekul Adsorpsi Hidrogen pada Carbone Nanotube dengan Variasi Chirality dan temperatur Menggunakan Kode LAMMPS, Journal of Energy, Material, and Instrumentation Technology, Vol. 2 No. 2, 2021

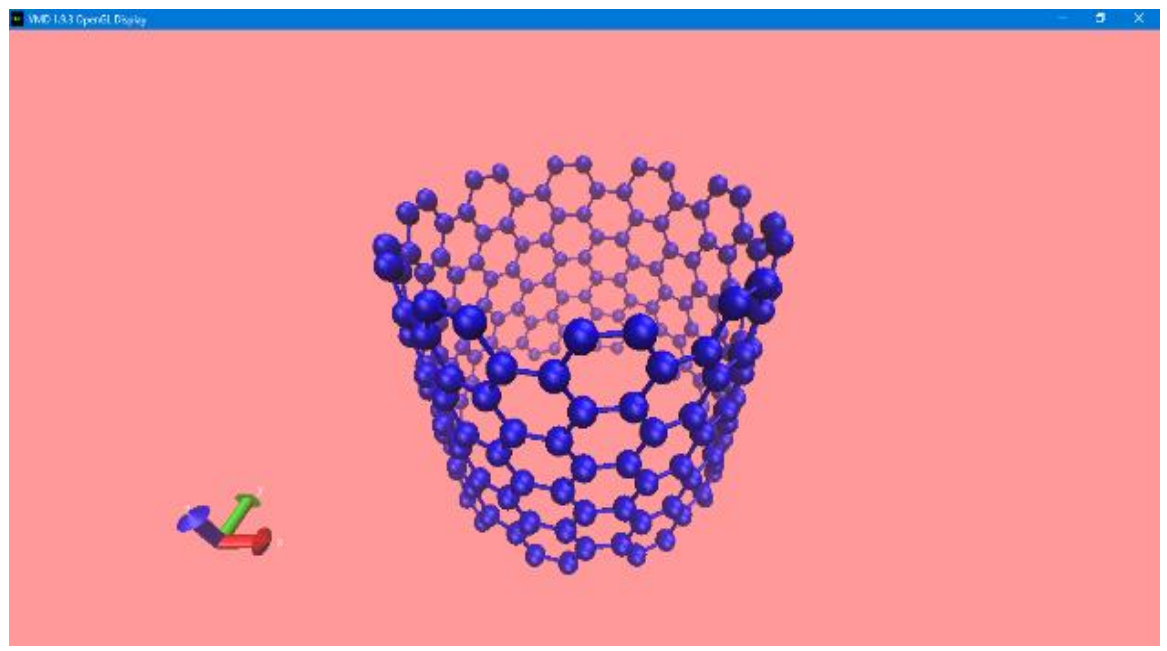

Gambar 3. Pembentukan CNT pada VMD

Langkah selanjutnya adalah menggabungkan output geometri Hidrogen dari Avogadro atau memasukkan output file yang berisi koordinat hidrogen kedalam VMD, dimana output file CNT juga sudah ada di VMD. Setelah Carbon Nanotube dapat bersatu dengan Hidrogen maka penulis dapat menyesuaikan jarak antara hidrogen dengan karbon seperti pada Gambar 4.

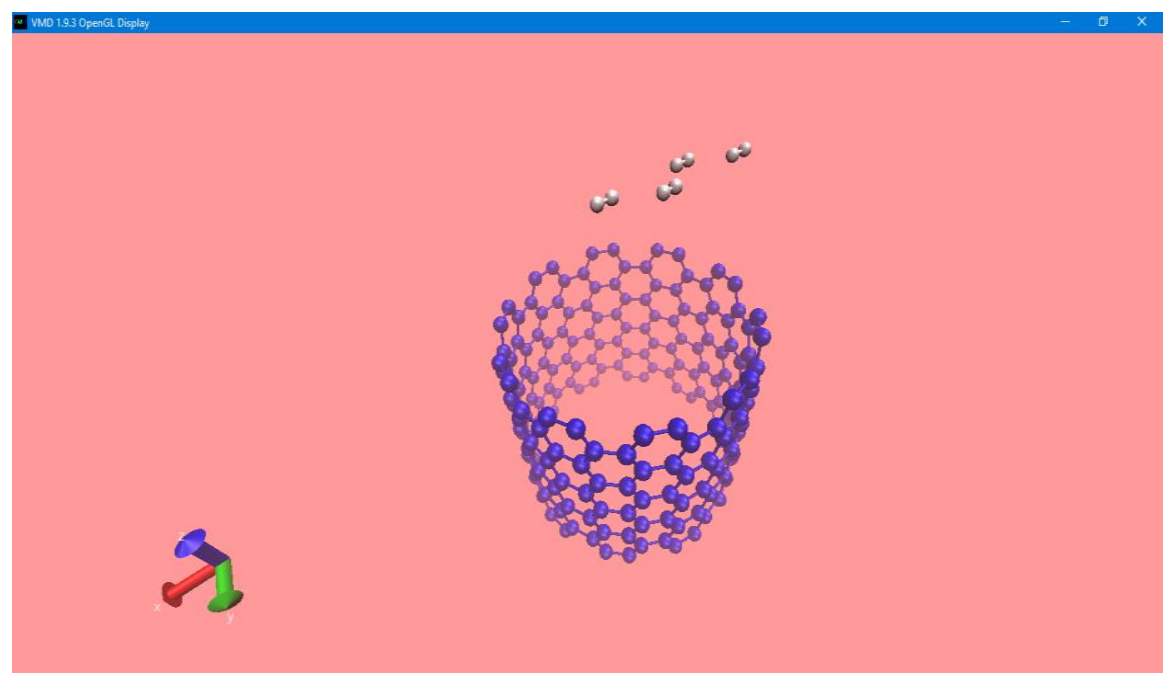

Gambar 4. Penggabungan CNT dengan Hidrogen pada VMD

Program LAMMPS. Pembentukan input script yang digunakan dalam simulasi LAMMPS menggunakan piranti Notepad++ yang disimpan dengan ekstensi "in". Input script LAMMPS berisi informasi yang harus diberikan sebelum simulasi. Menjalankan file input melalui command prompt, dengan membuka folder tempat penyimpanan file input script melalui command prompt kemudian melakukan run dengan mengetikkan "lmp_serial -i (nama file)" lalu enter. Hasil output yang diperoleh terdapat dua jenis file yaitu file dump untuk visualisasi dan file log.lammps untuk menganalisis hasil adsorpsi hidrogen pada CNT, salah satunya waktu dalam simulasi.

\subsection{Metode Analisis}

Sebelum menggunakan software LAMMPS langkah pertama pada penelitian ini yaitu pembentukan hidrogen pada software Avogadro. Pada Avogadro pembentukan hidrogen diletakkan secara bebas, kemudian setelah diperoleh output file koordinat hidrogen dari Avogadro, penelitian di lanjutkan dengan pembentukan CNT pada sofware VMD. Setelah di peroleh output file koordinat CNT pada VMD, selanjutnya menggabungkan output file koordinat hidrogen, dimana kedua material menggunakan koordinat $\mathrm{x}$, y dan $z$. Kemudian keduanya digabungkan melalui VMD pada menu Extensions pada VMD dan memilih opsi Tk Console.

Setelah output file koordinat hidrogen dan koordinat carbon nanotube berhasil tergabung maka di peroleh data file yang dapat digunakan sebagai read data untuk input script pada LAMMPS. Setelah berhasil running maka diperoleh dua jenis output file yaitu "log.lammps" yang berisi data untuk menganalisis hasil simulasi adsorpsi 
hidrogen dan mengetahui jumlah tekanan, energi dan parameter-parameter lain yang mempengaruhi simulasi adsorpsi hidrogen. Output file kedua yaitu "dump" yang merupakan data untuk visualisasi hasil simulasi, kemudian di visualisasikan pada VMD dan di peroleh hasil visualisasi seperti Gambar 5. Hasil visualisasi merupakan gambar bergerak, dimana atom-atom hidrogen akan masuk kearah dalam CNT melalui pori-pori CNT yang memuai akibat di berikan suhu panas, sesuai dengan fisisorpsi atom-atom hidrogen akan di tahan secara bebas pada permukaan dalam CNT.

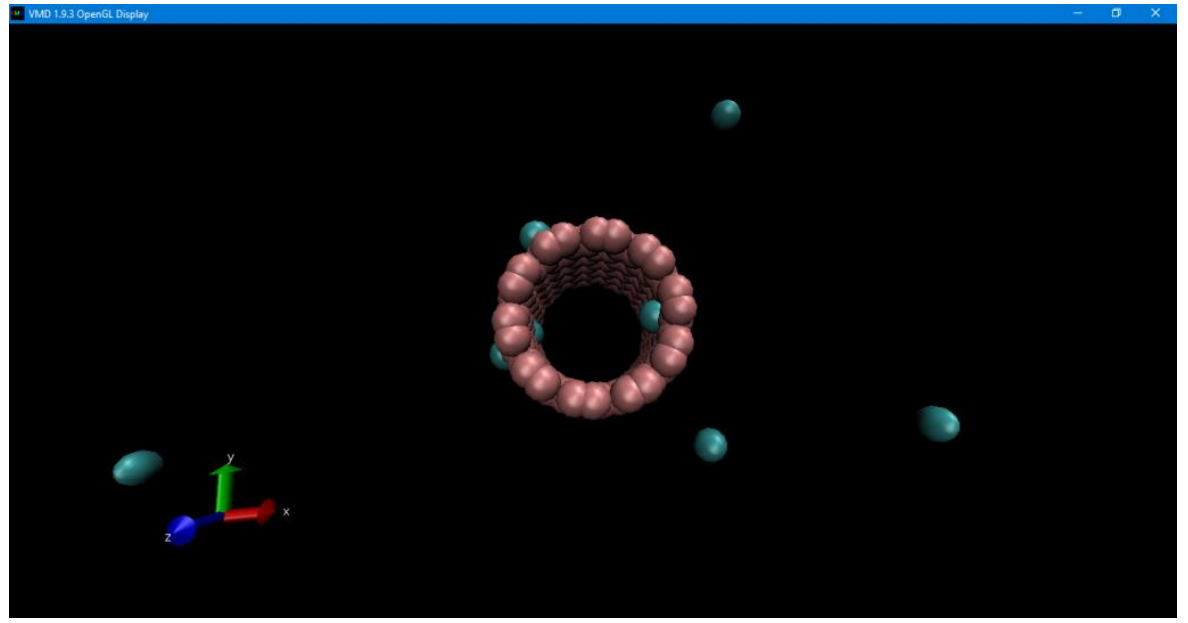

Gambar 5. Contoh visualisasi simulasi adsorpsi hidrogen pada VMD

\section{Hasil Dan Pembahasan}

\subsection{Hasil dan Data Pengamatan}

Hasil output simulasi menggunakan kode LAMMPS berupa file log.lammps dan file dump. File log.lammps berisi data-data informasi yang diperoses oleh LAMMPS. Data tersebut berupa parameter-parameter yang kita inginkan dalam simulasi dan file dump merupakan file yang akan digunakan sebagai file intput pada software VMD untuk menampilkan visualisasi hasil simulasi adsorpsi hidrogen pada CNT. Terdapat tiga jenis struktur pada CNT yang disebut dengan index chirality armchair, chiral dan zigzag dengan masing-masing nilai index m berbeda sesuai dengan ketentuan penggulungan CNT. Penyerapan optimum terjadi pada run 10000 dan penyerapan optimum index chirality armchair pada temperatur $100 \mathrm{~K}$, chirality chiral pada temperatur $100 \mathrm{~K}$ dan chirality zigzag pada temperatur $100 \mathrm{~K}$. Metode simulasi adsorpsi hidrogen pada CNT ini menggunakan simulasi dinamika molekul kode LAMMPS dengan potensial interatomik Lennard-Jones dan gaya Van der Waals.

\subsection{Simulasi Adsorpsi Hidrogen pada CNT}

Hasil output LAMMPS berupa file log.lammps dan file dump, kemudian dianalisis menggunakan grafik Excel. Pada penelitian ini terdapat tiga run yang digunakan yaitu run 10000, run 20000 dan run 30000 dengan tiga index chirality yaitu armcahir dengan nilai index $\mathrm{n}$ sebesar $10 \mathrm{~nm}$, m sebesar $10 \mathrm{~nm}$ dan diameter $11,28 \mathrm{~nm}$, chirality chiral memiliki nilai $\mathrm{n}$ sebesar $10 \mathrm{~nm}$, m sebesar $6 \mathrm{~nm}$, diameter sebesar $9,11 \mathrm{~nm}$ dan chirality sigzag memiliki nilai $\mathrm{n}$ sebesar $10 \mathrm{~nm}, \mathrm{~m}$ sebesar $0 \mathrm{~nm}$ dan diameter sebesar $6,51 \mathrm{~nm}$. Perhitungan diameter CNT dapat dilihat pada Persamaan 1.

$$
d=\frac{a}{\pi} \sqrt{\left(n^{2}+n m+m^{2}\right)}
$$

Pada Persamaan 1, nilai a sebesar $2.046 \mathrm{~nm}$ dan $\mathrm{n}, \mathrm{m}$ merupakan vektor kiral pada SWNT (Single Walled Carbone Nanotube) atau CNT yang digunakan pada simulasi.

1. Variasi suhu untuk chirality armchair. Analisis pada index chirality armcahair dengantemperatur $100 \mathrm{~K}, 200 \mathrm{~K}$ dan $300 \mathrm{~K}$ dapat dilihat pada Gambar 6. 


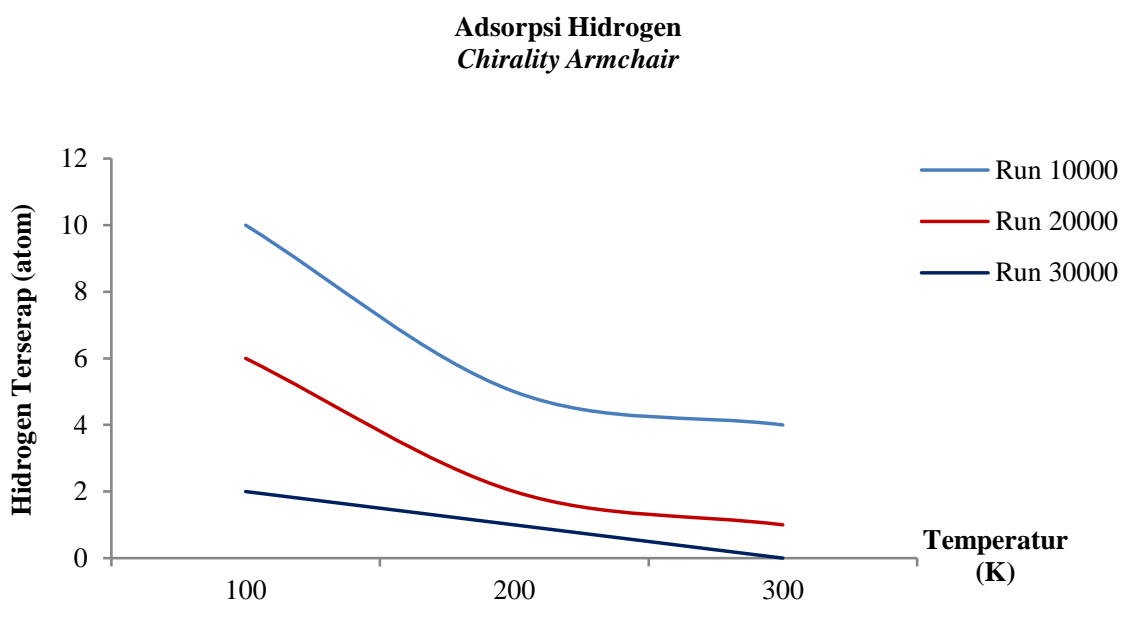

Gambar 6. Grafik temperatur terhadap jumlah hidrogen terserap chirality armchair

Berdasarkan metode simulasi menggunakan gaya Van der Waals, pada Gambar 6 yang merupakan grafik temperatur terhadap jumlah hidrogen terserap dengan Run 10000, 20000 dan 30000 pada chirality armchair dapat dilihat bahwa semakin tinggi temperatur semakin kecil kapasitas penyerapan hidrogen, karena semakin tinggi temperatur gaya tarik-menarik (Van der Waals) antara hidrogen dan CNT semakin lemah. Dengan tinggi temperatur $100 \mathrm{~K}, 200 \mathrm{~K}$ dan $300 \mathrm{~K}$, saat run 10000, hidrogen yang terserap berturut-turut sebesar 10 atom, 5 atom dan 4 atom. Lalu run menjadi 20000, hidrogen terserap berturut-turut sebesar 6 atom, 2 atom, 1 atom dan saat run 30000 adsorpsi hidrogen sebesar 2 atom, 1 atom dan 0 atom.

2. Variasi suhu untuk chirality chiral. Analisis pada index chirality chiral dengan tinggi temperatur berturut-turut $100 \mathrm{~K}, 200 \mathrm{~K}$ dan $300 \mathrm{~K}$ dapat dilihat pada Gambar 7.

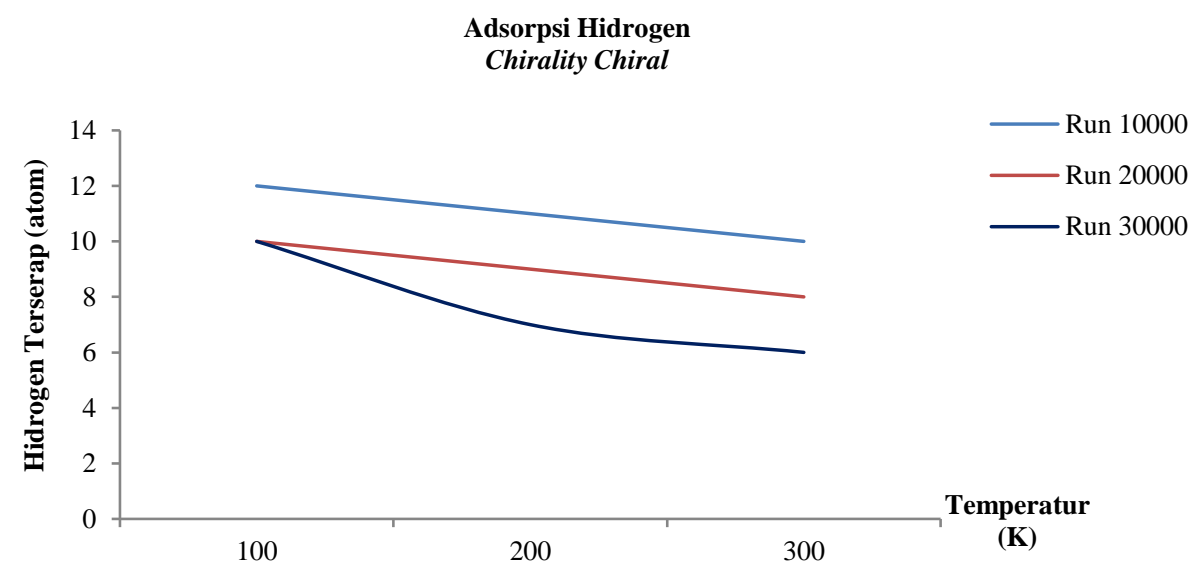

Gambar 7. Grafik temperatur terhadap jumlah hidrogen terserap chirality chiral

Berdasarkan Gambar 7, run 10000, 20000 dan 30000 dengan tinggi temperatur yaitu $100 \mathrm{~K}, 200 \mathrm{~K}$ dan 300 $\mathrm{K}$, diperoleh kapasitas adsorpsi hidrogen pada chirality chiral pada run 10000 berturut-turut sebesar 12 atom, 11 atom dan 10 atom. Run 20000 sebesar 10 atom, 9 atom dan 8 atom. Terakhir dengan run 30000 kapasitas adsorpsi setiap temperatur berturut-turut sebesar 10 atom, 7 atom dan 6 atom.

3. Variasi suhu untuk chirality zigzag. Analisis pada index chirality zigzag, dengan tinggi temperatur berturutturut $100 \mathrm{~K}, 200 \mathrm{~K}$ dan $300 \mathrm{~K}$ dapat dilihat pada Gambar 8. 


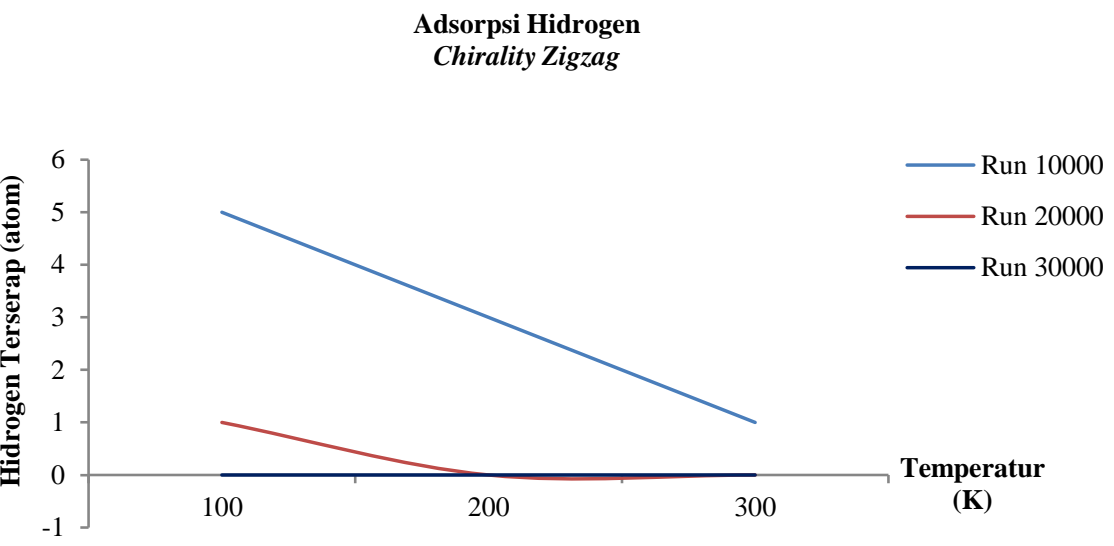

Gambar 8. Grafik temperatur terhadap jumlah hidrogen terserap chirality zigzag

Pada Gambar 8 dengan run 10000, 20000 dan 30000 temperatur yang digunakan pada simulasi sama seperti grafik sebelumnya yaitu $100 \mathrm{~K}, 200 \mathrm{~K}$ dan $300 \mathrm{~K}$. Kapasitas adsorpsi pada chirality zigzag run 10000 berturut-turut pada setiap temperatur sebesar 5 atom, 3 atom dan 1 atom. Saat run 20000 berturut-turut sebesar 1 atom 0 atom dan 0 atom. Saat run 30000 pada semua temperatur tidak ada hidrogen yang teradsorpsi atau 0 atom.

4. Suhu atau temperatur terbaik pada setiap variasi chirality. Terdapat tiga variasi chirality pada penelitian, yaitu armchair, chiral dan zigzag dengan tiga variasi run dapat dilihat pada Gambar 9.

\section{Adsorpsi Hidrogen Pada Suhu Terbaik} $\mathbf{T}=100 \mathrm{~K}$

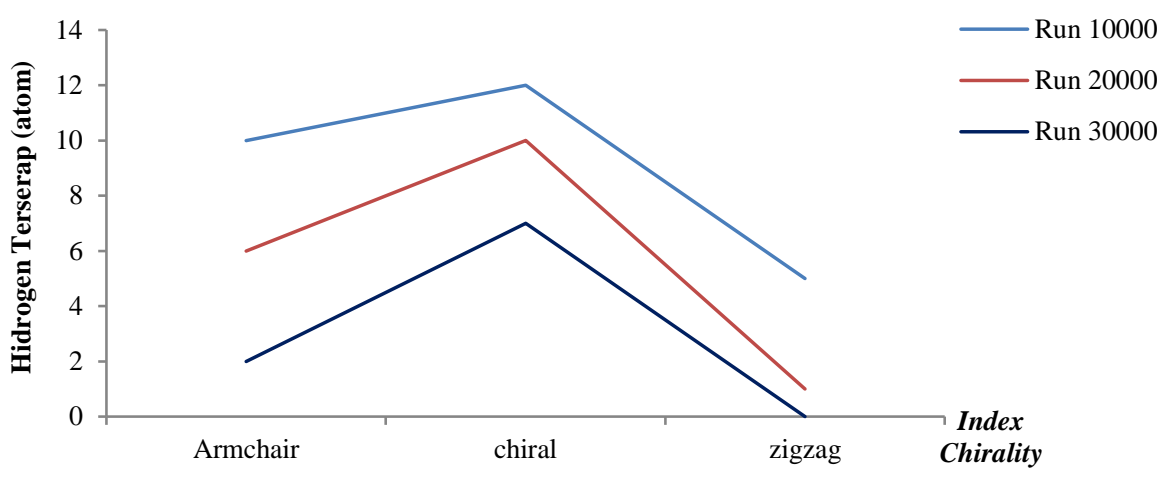

Gambar 9. Grafik penyerapan hidrogen terhadap variasi chirality pada suhu terbaik

Pada Gambar 9 terlihat variasi chirality pada suhu terbaik atau menjadi penyerapan optimum dalam simulasi dengan tinggi suhu yaitu $100 \mathrm{~K}$ dan tiga variasi run berbeda yaitu run 10000, 20000 dan 30000 . Untuk chirality armchair adsorpsi hidrogen optimum pada setiap run berturut-turut 10 atom, 6 atom dan 2 atom, chirality chiral berturut-turut 12 atom, 10 atom dan 10 atom, chirality zigzag sebesar 5 atom, 1 atom dan run 30000 pada chirality zigzag tidak ada hidrogen terserap (0 atom).

5. Pengaruh run terhadap chirality terbaik (chirality chiral) dan variasi temperatur. Analisis pada temperatur yang digunakan dalam penelitian yaitu $100 \mathrm{~K}, 200 \mathrm{~K}$ dan $300 \mathrm{~K}$ dan run 10000, 20000 dan 30000 dapat dilihat pada Gambar 10. 


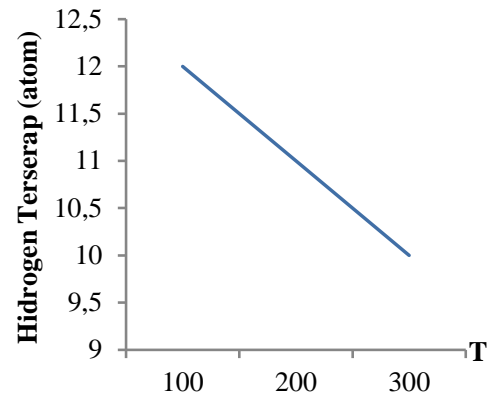

Run 10000

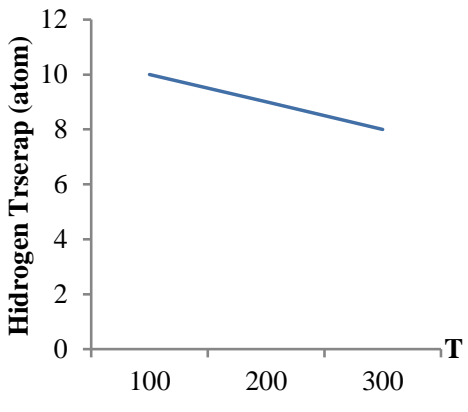

Run 20000

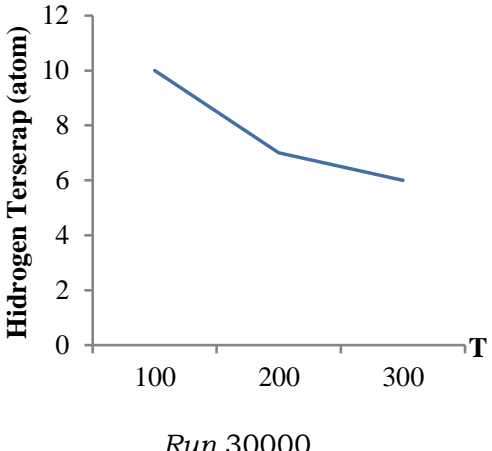

Run 30000

Gambar 10. Pengaruh Run terhadap chirality chiral dan variasi temperatur

Pada penelitian ini terdapat tiga variasi running yang digunakan yaitu 10000, 20000 dan 30000 dengan tiga variasi chirality yaitu armchair, chiral dan zigzag, serta tiga variasi temperatur yaitu $100 \mathrm{~K}, 200 \mathrm{~K}$ dan $300 \mathrm{~K}$. Diantara tiga variasi chirality, chirality chiral merupakan yang terbaik dalam penyerapan optimum hidrogen. Pada Gambar 10 terlihat bahwa setiap variasi running pada chirality cihral, saat temperatur semakin tinggi hidrogen yang terserap semakin sedikit dan diantara ketiga variasi running penyerapan optimum terjadi saat running 10000 . Pada penelitian ini pengaruh running adalah pada waktu proses simulasi, ketika run semakin banyak maka proses simulasi penyerapan hidrogen pada CNT semakin lama. Karena suhu yang digunakan pada penelitian ini cukup besar dan semakin besar, maka semakin lama proses simulasi pori-pori CNT semakin besar akibat memuai dan gaya Van der Waals semakin lemah sehingga hidrogen yang terserap semakin sedikit.

\subsection{Hasil Adsorpsi Hidrogen pada Carbone Nanotube}

Setelah dilakukan penelitian simulasi MD adsorpsi hidrogen pada carbone nanotube kode LAMMPS, diperoleh data hasil simulasi pada Tabel 1. Terdapat data input simulai antara lain index chirality, jumlah atom dan temperatur (Kelvin) serta data output meliputi, waktu (detik) dan penyerapan hidrogen (atom). Data berikut merupakan data penyerapan optimum hidrogen pada CNT yaitu saat run 10000.

Tabel 1. Nilai hasil simulasi adsorpsi hidrogen pada setiap index chirality run 10000

\begin{tabular}{cccccccc}
\hline No & $\begin{array}{c}\text { Index } \\
\text { Chirality }\end{array}$ & $\begin{array}{c}\mathbf{n} \\
(\mathbf{n m})\end{array}$ & $\begin{array}{c}\mathbf{n} \\
(\mathbf{n m})\end{array}$ & Atom & $\begin{array}{c}\text { Temperatur } \\
(\mathbf{K})\end{array}$ & $\begin{array}{c}\text { Waktu } \\
(\mathbf{d e t i k})\end{array}$ & $\begin{array}{c}\text { Hidrogen } \\
\text { Terserap } \\
(\text { Atom })\end{array}$ \\
\hline 1. & & & & & 100 & 2 & 10 \\
2. & Armchair & 10 & 10 & 384 & 200 & 3 & 5 \\
3. & & & & & 300 & 3 & 4 \\
4. & & & & & 100 & 4 & 12 \\
5. & Chiral & 10 & 6 & 416 & 200 & 4 & 11 \\
6. & & & & & 300 & 5 & 10 \\
7. & & & & & 100 & 2 & 5 \\
8. & Zigzag & 10 & 0 & 324 & 200 & 2 & 3 \\
9. & & & & & 300 & 2 & 1 \\
\hline
\end{tabular}

Jumlah atom dan nilai index $\mathrm{n}$, $\mathrm{m}$ setiap index chirality pada penelitian ini tetap sama. Data pada Tabel $\mathbf{1}$ menunjukkan perubahan waktu pada setiap temperatur, saat temperatur semakin tinggi waktu simulasi semakin lama atau tetap (konstan). Sedangkan hasil penyerapan optimum pada setiap chirality tepat pada temperatur terendah yaitu $100 \mathrm{~K}$ dan ketika temperatur semakin tinggi hasil penyerapan semakin kecil. Pada permukaan material karbon adsorpsi yang digunakan adalah jenis adsorpsi fisik atau fisisorpsi (Suci, 2016).

Adsorpsi fisik terjadi apabila adsorbat dan permukaan adsorben terikat dengan gaya Van der Waals saja (Widayatno dkk, 2017). Saat suhu tinggi hidrogen akan lebih cepat bergerak secara bebas pada ruang simulasi dengan waktu yang sesuai dengan Tabel 1. Pengaruh suhu menyebabkan interaksi gaya Van der Waals melemah, sehingga ketika pergerakan hidrogen semakin cepat, maka semakin sulit CNT menyerap hidrogen. Saat suhu meningkat atau lebih tinggi, maka kapasitas adsorpsi hidrogen menjadi semakin kecil (Suci, 2016).

\subsection{Visualisasi Adsorpsi Hidrogen pada CNT}


VMD telah dirancang dengan kemampuan untuk menganimasikan simulasi dinamika molekuler (MD), yang diimpor dari file atau dari koneksi langsung ke simulasi MD yang sedang berjalan (Humphrey dkk, 1996). Berikut merupakan visualisasi VMD penyerapan optimum pada run 10000 dan temperatur $100 \mathrm{~K}$ pada index chirality armchair, chiral dan zigzag yang diberikan pada Tabel 2.

Tabel 2. Hasil visualisasi adsorpsi hidrogen pada CNT chirality armchair, chiral dan zigzag run 10000

\begin{tabular}{|c|c|c|c|}
\hline $\begin{array}{c}\text { Index } \\
\text { Chirality }\end{array}$ & $\begin{array}{l}\text { Diameter } \\
(\mathbf{n m})\end{array}$ & $\begin{array}{c}\text { Temperatur } \\
\text { (K) }\end{array}$ & Visualisasi \\
\hline Armchair & 11,28 & 100 & \\
\hline & & & - \\
\hline Chiral & 9,11 & 100 & \\
\hline Zigzag & 6,51 & 100 & \\
\hline
\end{tabular}

Berdasarkan Tabel 2, terdapat hasil visualisasi dengan dengan index chirality yang berbeda. Masing-masing chirality memiliki nilai index $\mathrm{n}$, m yang berbeda, sehingga jumlah atom juga berbeda. Armchair memiliki total atom sebesar 384 atom dengan 360 atom CNT dan 24 atom hidrogen, kapasitas adsorpsi hidrogen sebesar 10 atom. Chiral memiliki total atom sebesar 416 atom, dengan 392 atom CNT dan 24 atom hidrogen, kapasitas adsorpsi hidrogen sebesar 12 atom. Zigzag memiliki total atom 324 atom, dengan 300 atom CNT 24 atom hidrogen dan kapasitas adsorpsi sebesar 5 atom. Tekanan yang dihasilkan dari penyerapan optimum ini, saat diberi temperatur $100 \mathrm{~K}$ pada chirality armchair sebesar 1,05 atm, chirality chiral sebesar 246,19 atm dan chirality zigzag sebesar $14159,03 \mathrm{~atm}$. Ketiga chirality memiliki volume yang konstan sebesar $59140 \mathrm{~nm}$ dan diameter yang berbeda sesuai dengan index $\mathrm{n}$ dan $\mathrm{m}$ yang mewakili pembungkusan graphene menjadi CNT (Varshney, 2014).

Visualisasi pada VMD mendapatkan bentuk tiga dimensi dari adsorpsi, VMD juga memvisualisasikan secara presentasi video atau biasa disebut dengan visualisasi dinamis, sehingga visualisasi dapat menampilkan layaknya proses adsorpsi hidrogen pada CNT sebenarnya yang sedang berlangsung.

\section{Kesimpulan}

Metode simulasi adsorpsi hidrogen pada CNT menggunakan simulasi dinamika molekul kode LAMMPS dengan potensial interatomik Lennard-Jones dan gaya Van der Waals telah berhasil dilakukan. Pada proses simulasi, semakin kecil temperatur yang digunakan untuk simulasi adsorpsi hidrogen pada chirality Armcahir, Chiral dan Zigzag, maka semakin besar hidrogen yang dapat diserap. Semkain besar temperatur, semakin kecil hidrogen yang dapat diserap. Penyerapan optimum hidrogen dengan run 10000, 20000 dan 30000 pada chirality armchair berturut-turut sebesar 10 atom, 6 atom dan 2 atom. Penyerapan optimum hidrogen dengan run 10000, 20000 dan 30000 pada chirality chiral berturut-turut sebesar 12 atom, 10 atom dan 10 atom. Penyerapan optimum hidrogen dengan run 10000, 20000 dan 30000 pada chirality zigzag berturut-turut sebesar 5 atom, 1 atom dan 0 Atom. Hasil maksimum penyerapan hidrogen pada CNT saat run 10000 dengan tipe index chirality chiral.

\section{Ucapan Terima kasih}

Penulis mengucapkan terima kasih kepada Kepala Laboratorium Elektronika Dasar dan Instrumentasi dan Ketua Jurusan Fisika Fakultas Matematika dan Ilmu Pengetahuan Alam Universitas Lampung yang telah membantu dalam penyelesaian penelitian ini. 


\section{Daftar Pustaka}

Afief, Abdurrohman dan Isana SYL. 2017. Produksi Gas Hidrogen Menggunakan Elektroda Stainless Steel/Fe-CoNi Dengan Media Tepung Biji Rambutan (Nephelium lappaceum l.). Prosiding Seminar Nasional Kimia UNY 2017. 259-268.

Astuti, A.D dan A.B. Mutiara. 2009. Performance Analysis on Molecular Dynamics Simulation of Protein Using GROMACS. Thesis. Universitas Gunadarma.

Chandrasa, Ganesha Tri. 2009. Penelitian Hidrogen sebagai Bahan Bakar Sepeda Motor Listrik yang Berkesinambungan. Prosiding Seminar Nasional Daur Bahan Bakar 2009. 13-17.

Dzulfahmi, Ahmad. 2012. Simulasi Dinamika Molekuler Adsorpsi Hidrogen pada Carbon Nanotubes (CNT) dengan Variasi Panjang. Skripsi. Universitas Indonesia.

Giyatmi., Zaenul, Kamal, dan Damajati Melati. 2008. Penurunan Kadar Cu,Cr dan Ag Dalam Limbah Cair Industri Perak di Kotagede Setelah Diadsorpsi Dengan Tanah Liat Ddari Daerah Godean. Seminar Nasional IV SDM Teknologi Nuklir. 2-25.

Hakim, Lukman dan Intan Marsalin. 2017. Pemanfaatan Limbah Aluminium Foil Untuk Produksi Gas Hidrogen Menggunakan Katalis Natrium Hidroksida (NaOH). Jurnal Teknologi Kimia Unimal. 6(1). 68 - 81.

Hidayat, Aulia Fikri. 2019. Studi Evolusi Struktur pada Deposisi Tembaga Dalam Substrat Silikon Dengan Metode Dinamika Molekuler. Jurnal Matematika. 18(1). 21-28.

Humphrey, William., Andrew, Dalke, dan Schulten. 1996. VMD: Visual Molecular Dynamics. Journal of Molecular Graphics. 14. 33-38.

Jabbar, Abdul. 2012. Simulasi Dinamika Molekuler Adsorpsi Hidrogen pada Carbon Nanotubes (CNT) dengan Variasi Tempratur. Skripsi. Universitas Indonesia.

Kurniady, A., Yoga, Satria Putra, dan I. D. Faryuni. 2014. Studi Analisis Pengaruh Suhu, Tekanan dan Ukuran Pori Graphene Terhadap Dinamika Molekuler Adsorpsi Hidrogen. Prisma Fisika. 2(3). 59 - 66.

Lago, N Faginas., D, Yeni, F. Huarte, Y. Wang, M. Alcami dan F. Martin. 2016. Adsorption of Hydrogen Molecules on Carbon Nanotubes Using Quantum Chemistry and Molecular Dynamics. The Journal of Phisical Chemistry. 1(20). 6451-6458.

Prasodjo, Prolessara. 2010. Studi Kapasitas Adsorpsi Serta Dinamika Adsorpsi dan Desorpsi dari Nanotube Karbon Sebagai Penyimpan Hidrogen. Tesis. Universitas Indonesia.

Rayan, Baraa dan Anwar Rayan. 2017. Avogadro Program for Chemistry Education: To What Extent can Molecular Visualization and Three-dimensional Simulations Enhance Meaningful Chemistry Learning?. World Journal of Chemical Education. 5(4). 136-141.

Santoso, Mardi. 2012. Simulasi Dinamika Molekuler Adsorpsi Hidrogen pada Carbon Nanotubes (CNT) dengan Variasi Chirality. Skripsi. Universitas Indonesia.

Saputri, Yuriska Utagi. 2018. Hidroksi Lapis Ganda Mg-Fe dan Ca-Fe Sebagai Adsorben Gas Hidrogen. Skripsi. Universitas Sriwijaya.

Suci, Farradina Choria. 2016. ZTC: Sintesis, Karakterisasi, Mekanisme Penyimpanan, dan Studi Adsorpsi $\mathrm{H}_{2}$. Jurnal Ilmu dan Aplikasi Teknik. 1(1). 1-12.

Sutanti, Retno dan Susi Handayani. 2013. Studi Pengaruh Jenis dan Komposisi Katalis Pada Proses Pertumbuhan Carbon Nanotube (CNT). Dengan Metode Catalytic Chemical Vapour Deposition (CCVD) Jurnal Teknologi Kimia dan Industri. 2(2). 135-147.

Varshney, Kalpna dan Assistant Professor. 2014. Carbon Nanotubes: A Review on Synthesis, Properties and Applications. International Journal of Engineering Research and General Science. 7(4). 660-677.

Widayatno, Tri., Teti, Yuliawati, dan Agung Adi Susilo. 2017. Adsorpsi Logam Berat (Pb) Dari Limbah Cair Dengan Adsorben Arang Bambu Aktif. Jurnal Teknologi Bahan. 1(1). 17-23. 
Zuttel, Andreas. 2003. Materials For Hydrogen Storage. Review Featue. 1-33. 